\title{
EXPERIMENTS ON THE ESCAPE OF BACTERIA WITH THE SECRETIONS.
}

\author{
By C. S. Sherrington, M.A., M.D., Professor-Superintendent \\ of the Brown Institution, London.
}

IN several of the specific infective diseases the secretions of the infected individual sometimes contain the organised virus. The practical importance of this fact is obvious ; the secreta may become foci for dissemination of the disease. The phenomenon also calls up certain problems of theoretical rather than practical interest, yet worthy of consideration by the student of pathology. In those diseases in which the infective matter is known to be bacterial, its appearance in the secreta must mean that the bacteria have traversed in a living condition at least one living membrane of the animal body. What conditions obtain during such a transit? The question has been answered differently by various observers, and the object of the experiments recorded in the present paper has been to examine some of the controverted points anew.

\section{Previous Observations.}

It will be remembered that Hoffman and Langerhaus $\left({ }^{1}\right)$, from experiments in which they injected powdered cinnabar into the circulation, concluded that the particles never passed into the urine. Riitimeyer ( $\left.{ }^{2}\right)$ came to a similar conclusion in experiments on the dog, but in the frog he found the particles quite frequently pass into the bladder. Bridges Adams ( $\left.{ }^{3}\right)$ detected fat globules in the urine of the dog, after intravenous injection of fresh milk. Wiener $\left({ }^{4}\right)$ found globules of oil in the urine after the introduction of fat into the peritoneal cavity. Maas $\left(^{5}\right)$ proved the presence of oil in the urine in certain cases of fracture of the long bones. Grawitz $\left(^{6}\right)$ injected the spores of moulds into the circulation, and believed that they could, after an interval, be seen with the microscope in the urine, although neither blood nor albumin were present. Kannenberg $\left({ }^{7}\right)$ noted that in relapsing fever the spirilla, even when very plentiful in the blood, were absent from the urine, except in one instance complicated by nephritis and hæmorrhages. Philippowicz $\left({ }^{8}\right)$ has recorded the presence of tubercle bacilli in the sediment of the urine in a case of 
acute general tuberculosis, in which no microscopic lesions of the urinary organs were detected; in two cases of ulcerative endocarditis, and in two of phlegmonous erysipelas he was able to cultivate streptococci from the urine, although at the autopsies no secondary lesions in the kidneys were detected. From the urine of two guinea-pigs dying of glanders, he obtained glanders bacilli in scanty number. He gives no information as to the method he employed in collecting the urine he examined, nor is the absence or presence of blood in the urine noted. It must be remembered that Ferraresi and Guanieri $\left.{ }^{9}\right)$ never detected glanders bacilli in the urine of a number of glandered guinea-pigs, although they always found them in the bile. Finkler and Prior $\left({ }^{10}\right)$ have recorded that in two out of three cases the Finkler spirillum was detected in the urine of guinea-pigs inoculated with it per duodenum. Also after injection of the Koch spirillum they once found the spirilla in a drop of urine taken from the pelvis of the ureter; twice they examined the urine for it without success. On the other hand, Tizzoni and Cattani (11) found the spirilla when injected into the circulation disappear from it after a time, without appearing in the urine, the bile, or the contents of the intestine. Emmerich and Buchner (12), after injecting bacteria into the blood, found that they escape in large numbers through the intestinal wall. Whether introduced intravenously or subcutaneously, or into the peritoneal sac, pathogenic bacteria penetrated the intestinal wall and escaped into the lumen of the gut. Emmerich and Buchner worked chiefly with $B$. neapolitanus, and it is to be remembered that this bacillus, if not identical with, is at least difficult to distinguish from, B. coli commune, a habitual denizen of the intestinal contents. In one experiment no obvious pathological change in the intestinal mucosa was observable, but in almost all there was blood in the contents of the intestine, and there were hæmorrhages in the mucosa.

Bollinger, May $\left({ }^{13}\right)$, and Bang $\left({ }^{14}\right)$ stated that $B$. tuberculosis is sometimes present in milk when the udder is not the seat of local tuberculosis. Both claim to have inoculated tubercle from the milk of Perlsucht cows with perfectly sound mammæ. Professor Bang $\left({ }^{62}\right)$ has recently materially modified his views upon this point. ${ }^{1}$ Koubasoff $\left({ }^{15}\right)$ believes that he has demonstrated the same thing not only for tubercle, but for anthrax and erysipelas. Cavagnis $\left({ }^{16}\right)$, however, did not find that the milk of tuberculous guinea-pigs communicated tuberculosis, nor did three young guinea-pigs suckled for long periods by a tuberculous parent become tuberculous. But tuberculosis was communicated by inoculating one pig with the bile from a tuberculous guinea-pig. Escherich (17) concludes that although the milk of the normal puerperium is absolutely free from bacteria, the milk in cases of puerperal fever may contain bacteria, even when no signs of mammary inflammation are detectable. He finds in it then cocci, namely, Staphylococcus pyogenes aureus and albus. To examine the matter further he has injected a mixture of these

1 For further references to the subject, see Arloing, "Leçons sur la Tuberculose," p. 386. 
two cocci intravenously in a bitch and in three guinea-pigs during lactation. The milk of these animals had repeatedly been shown before the injection to contain no bacteria at all. After the injection specimens taken at $2 \frac{1}{2}, 3,4,24$, and 48 hours contained the specific micrococci. Longard (18) has repeated and confirmed these results of Escherich. Wyssokowitsch's $\left({ }^{19}\right)$ investigation, carried out in Flügge's laboratory, contains the most explicit experimental evidence we have. Wyssokowitsch injected pure cultures of various species of micro-organisms into the blood, and thereafter tested, at successive intervals, the urine, the intestinal contents, and in some cases the milk, for the presence of the organisms injected. Microscopical examination of the fluids and the tissues was laid aside altogether as untrustworthy for the purpose in view, and in detecting the presence of bacteria Koch's method of plateculture was almost exclusively employed, with, in every case, a careful post-mortem search by inspection for microscopic lesions in the organs. In taking specimens of the secretion for examination great care was observed to avoid contamination with the blood, etc. Grawitz's experiments on the passage of mould-spores (aspergillus and penicillium) into the urine were repeated, but were not confirmed. In twenty-seven experiments, with twelve species of bacteria, chosen as not commonly causing local lesions in the kidney, Wyssokowitsch was unable in a single instance to detect the bacteria in the urine. On the other hand, in thirteen out of seventeen experiments with bacterial species, known to frequently give rise to local lesions in the renal tissue, the bacteria were found in smaller or greater numbers in the urine. In twenty-two experiments, employing fourteen bacterial species, only twice were the species introduced into the blood found in the content of the intestine, and on each of those occasions there were macroscopic hæmorrhages in the serosa and mucosa. The milk was only twice examined, and each time found absolutely free from germs. Wyssokowitsch concludes that passage of bacteria into the excreta occurs only when the blood containing them escapes through some breach of continuity in the excretory membrane, due to inflammatory or mechanical injury. Since his important research appeared numerous, chiefly incidental, observations have been published on the subject. Of these may be mentioned the results recorded by Koujajeff $\left({ }^{20}\right)$, by Neumann ( ${ }^{21}$ ), and by Karlinski (22), as to the occurrence of the bacillus of enteric fever in the urine of typhoid patients. These observers detected the presence of the bacilli in $\mathbf{3 5}$ cases out of 112 examined in all. In the urine of rabbits inoculated with typhoid bacilli, Trambusti and Maffucci $\left({ }^{23}\right)$ found the bacilli in great numbers, and in the bile as well. The last-mentioned workers found anthrax bacilli in the fæces, in the urine, and in one instance in the bile of guinea-pigs they had inoculated with anthrax. Microscopic examination revealed no necrotic, hæmorrhagic, nor inflammatory lesions in the kidneys, liver, or intestine. In rabbits inoculated with B. pyocyaneus, Charrin and Ruffer $\left({ }^{24}\right)$ have demonstrated the frequent occur- 
rence of the specific bacilli in the urine; the presence of hæmorrhages in the kidney, and even amyloid degeneration was also noted. Ruffer $\left({ }^{27}\right)$, from experiments partly with and partly independent of Charrin, considers that the urine of rabbits inoculated with B. pyocyaneus constantly contains the specific bacilli. He, with Charrin, has made the interesting observation that $B$. prodigiosus " passes with great rapidity into the urine" when injected in large doses. Dr. Ruffer informs me that nephritis is prominent among the lesions produced by this infection. Schweizer $\left({ }^{58}\right)$ records experiments in which a green fluorescent bacillus, after being injected into the renal artery, was found in quantity in urine collected from the ureter; the manner in which the urine was collected did not, however, exclude its possible contamination with blood. After the intravenous injection of $B$. coli communis and $B$. typh $i$ abdominalis in rabbits, those species appear in numbers in the bile, as has been proved by Blachstein $\left({ }^{26}\right)$. Corrado $\left({ }^{26}\right)$, from experiment, finds that certain species tend to appear in the bile after intravenous or subcutaneous injection with greater frequency than do other species; thus, the pneumococcus and $B$. anthracis with considerable frequency. The virulence of the germs is not diminished by their transit, but that of $B$. anthracis is impaired by the prolonged action of bile, as Straus and Chamberland $\left({ }^{54}\right)$ have earlier pointed out. Pernice and Scagliosi ( $\left.{ }^{51}\right)$ affirm that Staphylococcus pyogenes aureus, $B$. anthracis, and $B$. pyocyaneus are after their intravenous injection constantly excreted in the bile, urine, gastric and intestinal juices, and in the semen; also that they pass constantly from the maternal to the foetal circulation. The excretion of them commences 6 hours after the inoculation, and may continue with innocuous species for 48 hours, with pathogenic species until death. Enriquez (22) asserts that healthy urines sometimes contain pyococci, a fact of importance if confirmed, because Shattock $\left({ }^{53}\right)$ has shown pyococci to be able to cause the alkaline fermentation of urine.

Babés $\left({ }^{29}\right)$ has concluded from experimental observation that the bacilli of glanders can penetrate uninjured mucous membranes: Cornil $\left({ }^{30}\right)$ has in some measure confirmed the observations of Babés. Dobroklouski ( ${ }^{60}$ ), in Cornil's laboratory, found that $B$. tuberculosis (var. avium), when administered with food, infected guinea-pigs, penetrating the healthy intestinal mucosa.

Nocard ( $\left.{ }^{61}\right)$ has observed that when injected into the mammary ducts of the goat $B$.tuberculosis continues to infect the animal's milk for a considerable time. Roth ( $\left.{ }^{31}\right)$ affirms that he has inoculated guinea-pigs with Ribbert's bacillus of enteritis of rabbits by rubbing the culture on the nasal mucosa and on the healthy skin. He was, however, not careful to avoid abrasion, and Schimmelbusch $\left({ }^{32}\right)$, after demonstrating that staphylococci, when rubbed into the human skin, produce pustules, thinks it very questionable whether in his own experiments, in which greater care was taken, small breaches of continuity were not produced. 
Regarding the penetration of the placental membranes by bacteria we recall the negative results of all the most careful researches on the passage of fine particles from the maternal blood into the fœtal, and especially the observation of Ahlfeld( $\left.{ }^{33}\right)$, that even after the ingestion of a meal rich in fat, when the maternal blood becomes loaded with the infinitely minute particles of the "molecular base," the plasma of the foetal blood remains absolutely free from them. Max Wolff's $\left({ }^{34}\right)$ careful research on the effects of inoculation of anthrax into guinea-pigs approaching their term, led him to the conclusion that the placenta offers, at all periods of pregnancy, an impassable barrier to $B$. anthracis, although he admits the possibility of its transit in exceptional cases, where pathological alteration of the placental structure has occurred. Lingard $\left(^{35}\right)$ also has proved that anthrax bacilli do not pass into the mother, or into other fotus of the litter when one member of the litter is inoculated in utero. Birch-Hirsehfeld and Lubarsch $\left({ }^{36}\right)$ point out that when the passage of bacteria from mother to fœtus occurs it is the more frequent the longer the period during which the bacilli have been circulating in the blood.

Experiments by Landouzy and H. Martin ( $\left.{ }^{56}\right)$, as also later by Birch-Hirschfeld and Schmorl $\left({ }^{57}\right)$, show that the fœtus of a tuberculous mother may contain B.tuberculosis, although no distinct tubercular lesions be present. Congenital tuberculosis, although infrequent, appears nevertheless to be of indisputable occurrence. ${ }^{1}$

Pasteur $\left({ }^{37}\right)$, Lister $\left({ }^{38}\right)$, Watson Cheyne $\left({ }^{39}\right)$, and Meissner $\left({ }^{40}\right)$ were the first to ascertain that the secretions and tissues of the healthy body do not contain bacteria, a fact that, although from time to time controverted, has eventually become a recognised and accepted truth; but that when bacteria have gained entrance to the body they may appear in the secreta, the above-cited evidence shows indisputably, although the more recent experiments declare, in opposition to the earlier, that the escape of the bacteria with the excreta occurs only along with hæmorrhage through the secreting membrane. This view stands in sharp opposition to the suggestion made by Cohnheim in $1882\left({ }^{41}\right)$, that the organism possesses in renal excretion a means of ridding itself, not merely of dissolved, but also of organised poisons, i.e. of pathogenic germs. Cohnheim stated also that to the excretion by uninjured kidneys of tubercle bacilli is referable the extension of tuberculous lesions to the urinary passages from other foci in the body.

\section{OWN EXPERIMENTS.}

For my observations I have inoculated with pure cultures either subcutaneously or intravenously, and have then examined the urine, the bile, and, in one or two instances, the aqueous humour. The bacterial

\footnotetext{
1 In reference to this subject, see the various observations cited by Arloing, "Leçons sur la Tuberculose," p. 137.
} 
species employed have been Bacillus anthracis, $B$. mallei, $B$. tuberculosis, $B$. cuniculicida, B. murisepticus, Ribbert's bacillus of diphtheritic inflammation of the intestine of the rabbit, $B$. pyocyaneus, and probably $B$. pneumonioe of Friedländer, Spirillum cholerce asiatica, and the FinklerPrior spirillum, and Staphylococcus pyogenes aureus. The species referred to as probably Friedländer's pneumo-bacillus, if not identical with that, resembled it most closely in morphological and pathogenic qualities. I obtained it from one of some plate-cultivations sown with dust from the window-ledge in a research room in the Hygienic Institute, Berlin, where the following experiments were commenced. It may be recalled that Uffelmann ( ${ }^{42}$ ) has reported that a colony of the pneumo-bacillus appeared in gelatine exposed by him to the air of a house cellar. Regarding the quantity employed for injection, enough bacteria were suspended in previously sterilised 75 per cent. sodium chloride solution to render the solution turbid and milky. A half cubic-centimetre of such an emulsion may, in the case of $B$. anthracis, be safely considered to contain at least 10 million germs, and in the case of $B$. murisepticus many times that number.

The Urine.-In order to test the urine for the presence in it of the specific micro-organisms introduced into the body, it is essential to obtain a sample uncontaminated during the process of obtaining it, either by the contents of the blood-vessels or by the tissue-juices. To ensure this my procedure was as follows. The animal was killed by an anæsthetic or by a blow on the back of the neck. I feared at first that in death by chloroform the hæmoglobin of the blood might pass into solution, and stain the excreta, leading to a false conception of the condition of the excreting membranes. The bladder was carefully exposed by reflecting the abdominal parietes after an incision had been carried along the linea alba from sternum to pubes. To the thin semi-transparent wall of the viscus, more or less distended with urine, was then applied a little copper disc fixed to a handle, and heated, but not to redness. Repeated applications were made until about a square centimetre of the bladder wall had been converted in its entire thickness into a dry, yellowishwhite, opaque eschar; a puckering at the edge of the eschar generally indicated when the eschar did actually involve the whole thickness of the wall of the viscus. The eschar was seized somewhere near its edge with sterilised forceps, and through its centre was thrust the end of a capillary pipette freshly drawn in the gas flame. Into a bulb blown about halfway up the pipette the urine ascended by capillary action. Sometimes instead of the capillary pipette a sterile syringe of the Koch pattern was used in order to collect larger samples than could be obtained with the pipette. One and the same sample of urine obtained was used for various tests, e.g. some drops of the sample were sown in plate-cultivations, some used for the micro-spectroscope, some for microscopical inspection, some for hanging drop cultures, etc. In certain cases the urine was obtained by gently compressing the abdomen in the 
living animal. In some early experiments on rabbits, not included in the appended list, samples of urine were obtained by catheterisation; but this method was given over on account of liability to slightly excoriate the mucous membrane. I am convinced that by pushing a sterilised pipette through an eschar, as above described, no risk of contamination, even when the blood-vessels are everywhere teeming with germs, need be feared. In two fatal cases of anthrax (rabbit) I cut out the greater part of the eschar with sterilised scissors, washed it in saline solution, and inoculated plates with the emulsion. The plates did not contain a single colony of anthrax at the end of seven days, although plates from the blood were opaque with colonies on the morning of the fourth day. I, on several (five) occasions, poured a broth-culture of the Finkler-Prior bacillus over the bladder, and then obtained the contents of the viscus in the way described; although bacilli from the contained urine appeared in the plate-cultures, no Finkler-Prior bacilli appeared at all. An objection to the method lies, however, in the process of making the eschar, sometimes causing a contraction of the bladder which evacuates it.

It will be noticed in the list of experiments that a considerable proportion were made on the mouse (white mouse). An advantage offered by that animal lies in the readiness with which the whole content of the bladder can be tested by cultivation plates, etc.; the quantity is small enough to be added, if need be, in toto, to the nutrient medium without altering the reaction, or producing turbidity that may embarrass specific identification of young colonies by the microscope. In the case of the bladder of the mouse it might be feared, perhaps, that the heat applied to the wall of the bladder, in order to make an eschar, might kill the micro-organisms possibly contained in the urine within. This possibility was controlled by placing the bulb of a small thermometer immersed in three drops of water inside the excised bladder against the inner face of the mucosa, and then producing an eschar involving the thickness of the wall. The thermometer, originally at $17^{\circ} \mathrm{C}$, never during the little operation exceeded $33^{\circ} \mathrm{C}$.

For plate-cultures a large portion of the sample of urine was always sown in one or several "original" plates, and from each "original" a first and second dilution were always made; the first dilution containing three "loops" of the original, the second dilution three "loops" of the first. When the specific colonies-diagnosed in doubtful cases with the microscope - were numerous, they were counted with the "counting apparatus," or in rolled tube-plates by V. Esmarch's counter. "Countless" in the Table means too numerous for counting with the "counter."

Besides taking care to procure the sample of urine free from outside contamination with the tissues, it is necessary to know whether the urine itself is not destructive of the bacteria that may be immersed in it for some hours. The action of the urine of the guinea-pig, rabbit, and mouse, I tested on each of the bacterial species employed, and, without 
details, it may suffice to say here that suspension in these urines for eight hours does not destroy any of the species tested, and, on the contrary, some of the species thrive in the urine, especially the (?) pneumo-bacillus in the urine of the white mouse. It may be remembered that some workers have employed human urine, to which a little peptone is added as a nutrient medium in place of the bouillon ordinarily employed.

Beyond ascertaining the fact of the presence or absence from the urine of the specific organisms introduced into the body, it seemed especially desirable to determine at the same time the presence or absence of blood in the secretion, as bearing on the question of the condition of the secreting membrane at the time. If, in the secretion, the red corpuscles of the blood be detectable, it is fair to assume that both the blood-vessel walls and the secreting membrane have suffered severe injury, amounting, it may be, to actual rupture. Blood is rapidly laked when diluted with even alkaline urine; the hæmoglobin is soon dissolved out of a number of the corpuscles; the colourless stromata in the urine may sometimes elude even a careful search with the microscope; in addition, therefore, to microscopical inquiry, the spectroscope has been employed for the detection of admixture of the urine with blood. Serial sections were in a few cases prepared from the kidney, and searched with the microscope for hæmorrhages, etc. ; but it was soon felt that little weight can be attached to even a large amount of negative evidence thus obtained, unless every piece of the whole of both right and left organs be examined in the serial preparations (a labour greater than I have attempted). The mucosa of the ureters and bladder have been examined systematically for macroscopic hæmorrhages, and in the few observations with glanders and tuberculosis the kidneys have always been carefully searched for macroscopic tubercles, etc.

At the time at which the sample was taken from the urine, a quarter of a cubic centimetre of blood was taken from the ear or from the heart, and sown into an "original" of three agar or gelatine cultures; thus the number of germs in the blood at the time was approximately ascertained. The rapidity with which bacilli injected, even in large quantity, into the circulation disappear from it is, in some cases, as striking as with carmine particles. Carmine grains suspended in 4 c.c. of "normal saline," to the extent of rendering the salt solution opaque, when introduced into the circulation of the rabbit, will disappear from the blood (taken from the ear) in the course of 10 to 15 minutes, or even less. The series of observations was sufficiently numerous, especially in the case of the pneumo-bacillus, to illustrate clearly the interval between subcutaneous inoculation and the appearance of the germs in the general circulation; also their succeeding numerical increase in the blood, progressing until death, as described originally in anthrax by Brauell $\left({ }^{43}\right), 1857$, and by Delaford $\left({ }^{44}\right), 1860$.

It sometimes happened that the subject of experiment, although left in no apparent extremity at 8.30 in the evening, was, at 6 o'clock next morning, found dead. A few of these cases were examined, but are 


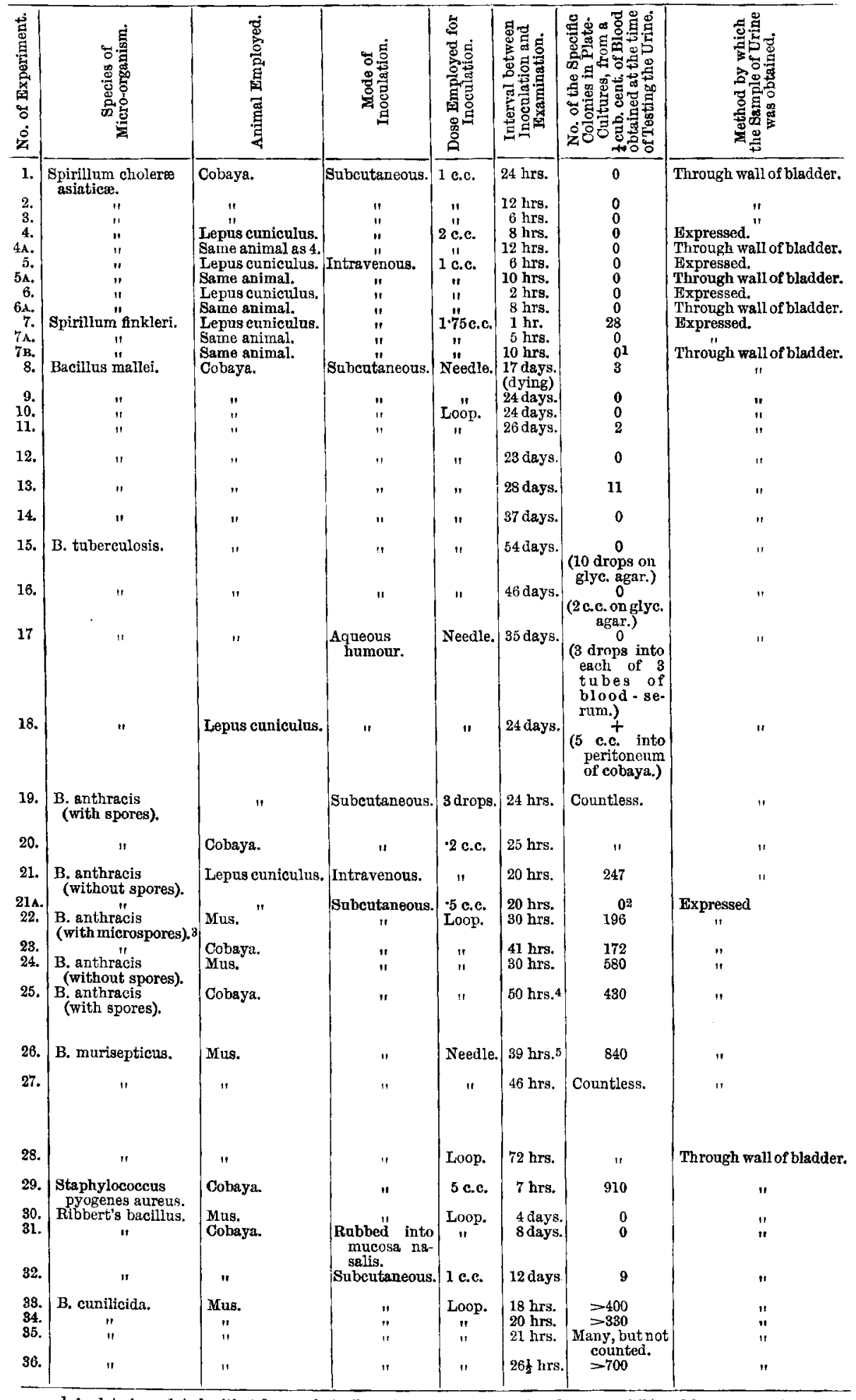

I A plate innculated with 5 drops of sterile salt solution, in which red marrow (rib) had been mashed, gave 9 colonies of Finkleri ; a plate from spleen, 21 ; plates from liver and kidneys, none.

2 Two drops of spleuic juice gave no colonies in three plate-cultivations. 


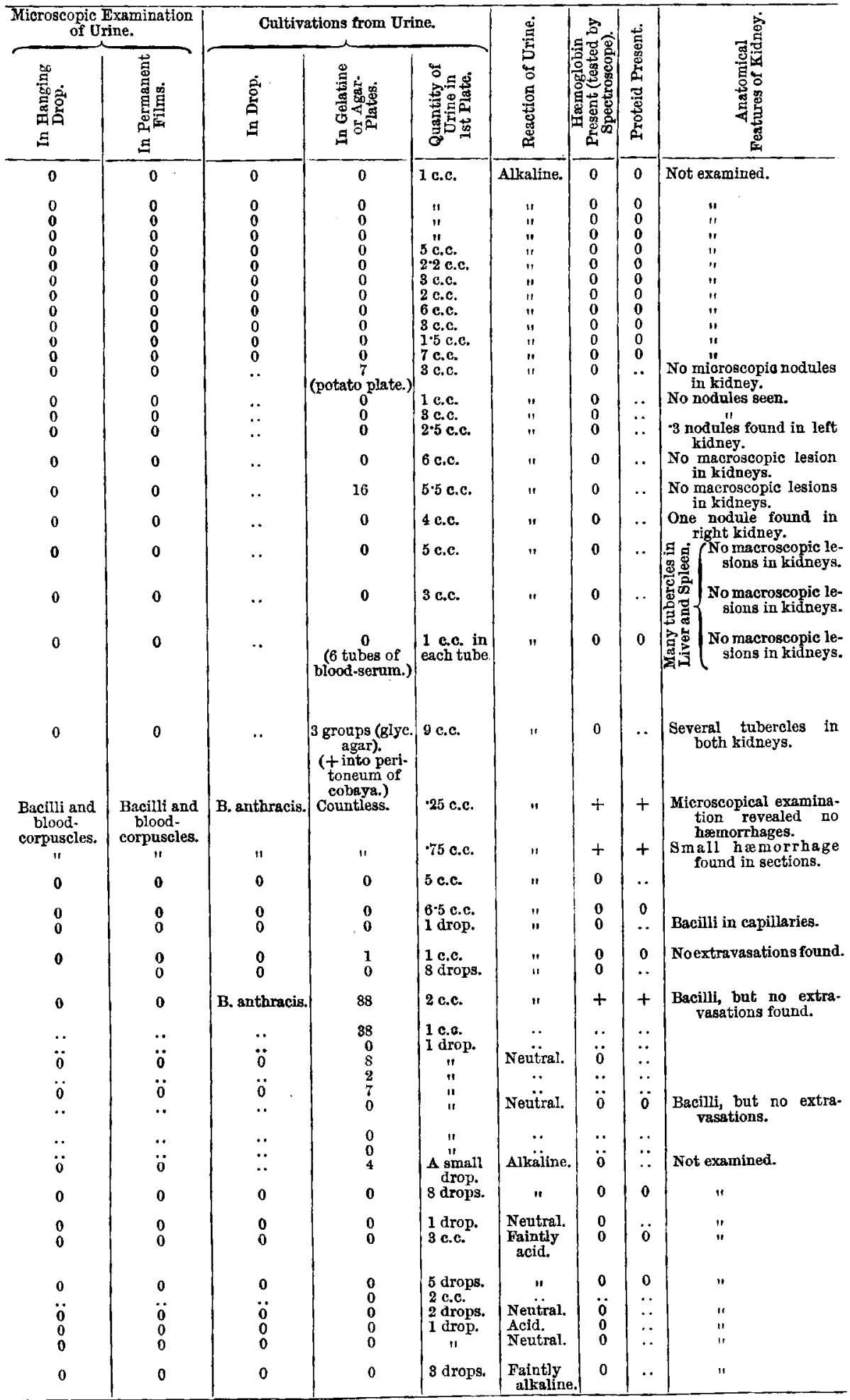




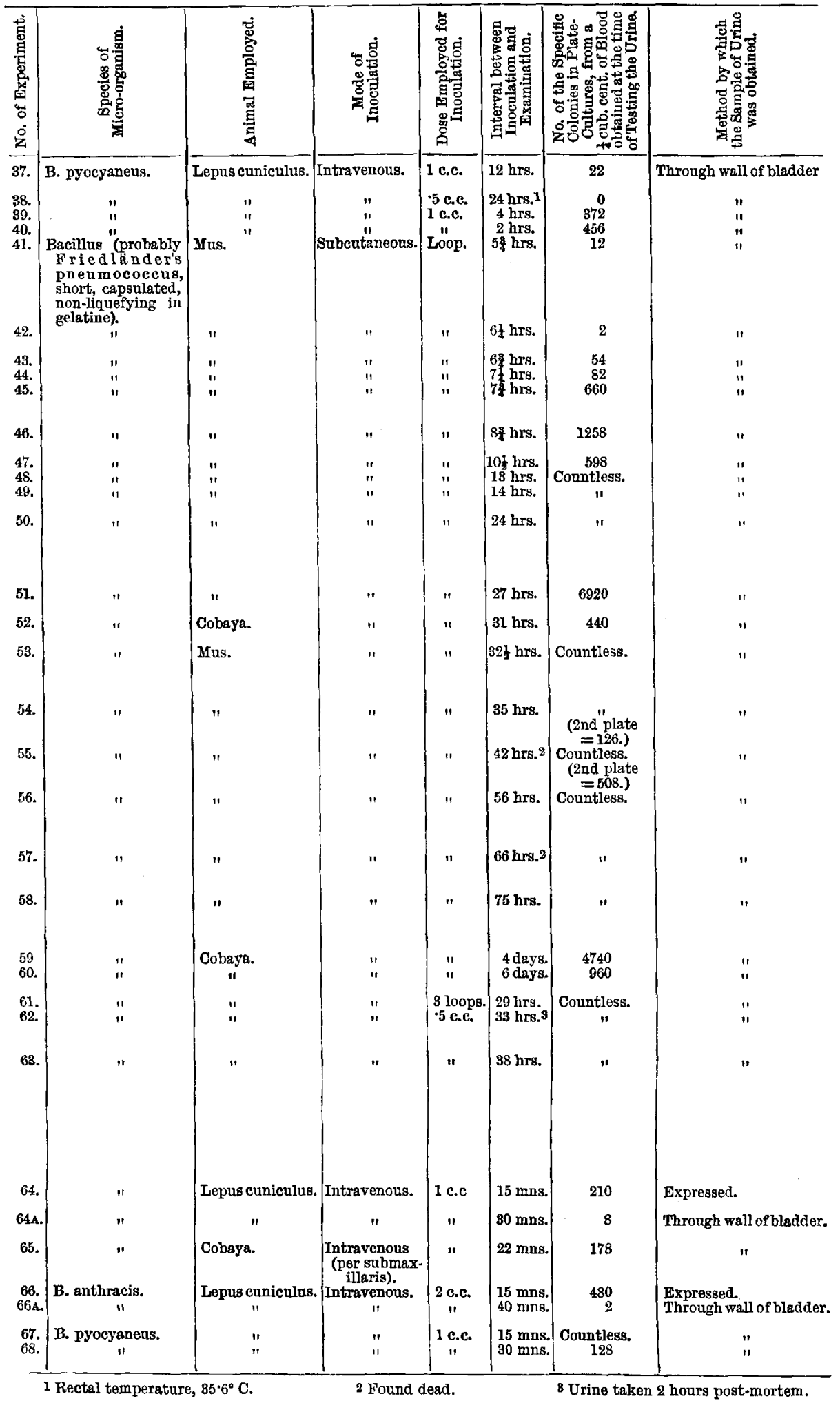




\begin{tabular}{|c|c|c|c|c|c|c|c|c|}
\hline \multicolumn{2}{|c|}{$\begin{array}{l}\text { Microscopic Examination } \\
\text { of Urine. }\end{array}$} & \multicolumn{3}{|c|}{ Cultivations from Urine. } & \multirow{2}{*}{ 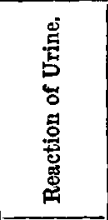 } & \multirow{2}{*}{ 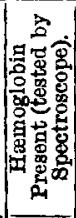 } & \multirow{2}{*}{ 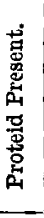 } & \multirow{2}{*}{ 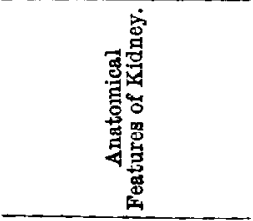 } \\
\hline 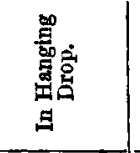 & 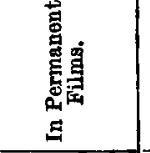 & $\begin{array}{l}\text { 高 } \\
\text { ä }\end{array}$ & 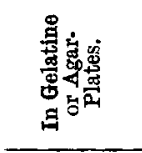 & 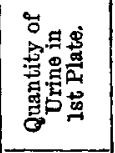 & & & & \\
\hline 0 & 0 & + & 233 & 1 c.c. & $\underset{\text { alkaline. }}{\text { Faintly }}$ & + & + & Not examined \\
\hline $\begin{array}{l}0 \\
0 \\
0 \\
0\end{array}$ & $\begin{array}{l}0 \\
0 \\
0 \\
0\end{array}$ & $\begin{array}{l}0 \\
+ \\
+ \\
0\end{array}$ & $\begin{array}{r}0 \\
104 \\
32 \\
0\end{array}$ & $\begin{array}{l}4 \text { c.c. } \\
10 \text { drops. } \\
5 \text { drops. } \\
2 \text { drops. }\end{array}$ & $\begin{array}{c}11 \\
11 \\
" 1 \\
\text { Neutral. }\end{array}$ & $\begin{array}{l}0 \\
0 \\
0 \\
0\end{array}$ & $\begin{array}{l}+ \\
0 \\
0 \\
\cdots\end{array}$ & " \\
\hline 0 & 0 & 0 & 0 & $"$ & Faintly & o &.. & $"$ \\
\hline $\begin{array}{l}\mathbf{0} \\
\mathbf{0} \\
0 \\
. .\end{array}$ & $\begin{array}{c}0 \\
0 \\
\text { A few bacilli. } \\
. .\end{array}$ & $\begin{array}{l}0 \\
0 \\
+ \\
. .\end{array}$ & $\begin{array}{r}0 \\
0 \\
152 \\
33\end{array}$ & $\begin{array}{l}3 \text { drops. } \\
4 \text { drops. } \\
3 \text { drops. } \\
1 \text { drop. }\end{array}$ & $\begin{array}{c}\text { Neutral. } \\
\text { Alkaline. } \\
\text { Neutral. } \\
\text {.- }\end{array}$ & $\begin{array}{l}0 \\
0 \\
0 \\
\cdots\end{array}$ & $\begin{array}{l}. . \\
. . \\
. .\end{array}$ & $\begin{array}{l}\text { Bacillitia the capillaries. } \\
\text { No extravasation. } \\
\text { Many bacilli. }\end{array}$ \\
\hline$\ddot{0}$ & $\ddot{0}$ & $\ddot{0}$ & $\begin{array}{r}19 \\
0\end{array}$ & 4 d"rops. & slightitly & $\ddot{0}$ & $\begin{array}{l}\cdots \\
\cdots\end{array}$ & Not examined. \\
\hline $\begin{array}{l}0 \\
0 \\
0\end{array}$ & $\begin{array}{l}0 \\
0 \\
0\end{array}$ & $\begin{array}{l}0 \\
0 \\
+\end{array}$ & $\begin{array}{r}0 \\
0 \\
\mathbf{9} \\
\mathbf{9}\end{array}$ & $\begin{array}{l}2 \text { drops. } \\
5 \text { drops. } \\
\text { A trace. }\end{array}$ & $\begin{array}{l}\text { Neutral. } \\
\text { Alkaline. } \\
\text { "I }\end{array}$ & $\begin{array}{l}0 \\
0 \\
0\end{array}$ & $\begin{array}{l}\ddot{ } \\
\ddot{*}\end{array}$ & $"$ \\
\hline $\begin{array}{l}\text { Bacilili and } \\
\text { ?blood. } \\
\text { corpuscles. }\end{array}$ & $\begin{array}{l}\text { Bacilli. } \\
\text {.. }\end{array}$ & $\ddot{t}$ & $\begin{array}{c}10 \\
6 \\
\text { Countless. }\end{array}$ & 1 drop. & Alkäine. & $\ddot{+}$ & $\ddot{+}$ & $\begin{array}{l}\text { Bacilli, but no hæmor- } \\
\text { rhage found. }\end{array}$ \\
\hline .. & $\because$ & $\ddot{\ddot{\theta}}$ & $"$ & $"$ & $\because$. & $\because$. & $\ddot{*}$ & \\
\hline$\ddot{0}$ & $\ddot{0}$ & $\ddot{0}$ & $\begin{array}{ll}1 " \\
0 \\
0\end{array}$ & 2 drops. & Alkaline. & $\ddot{0}$ & $\ddot{.}$ & Not examined. \\
\hline$\ddot{0}$ & $\ddot{0}$ & $\ddot{0}$ & $\begin{array}{l}0 \\
0 \\
0\end{array}$ & $\begin{array}{l}1 \text { arop. } \\
4 \text { c.c. } \\
3 \text { drone }\end{array}$ & Alkäine. & $\because$ & $\ddot{x}$ & $"$ \\
\hline $\begin{array}{c}\text { Bacilii (no } \\
\text { blood- }\end{array}$ & $\begin{array}{l}\text { Bacilli. } \\
\text {.. }\end{array}$ & $\ddot{+}$ & Countless. & $\begin{array}{c}3 \text { drops. } \\
1 " \\
11\end{array}$ & $\begin{array}{c}\text { Neutral. } \\
. .\end{array}$ & $\begin{array}{l}\ddot{0} \\
. .\end{array}$ & $\ddot{\ddot{.}}$ & No extra vasations found. \\
\hline $\begin{array}{c}\text { corpuscles). } \\
\text {.. }\end{array}$ & $\because$ & $\ddot{\because}$ & $" 1$ & $\begin{array}{l}2 \text { drops. } \\
1 \text { drop. }\end{array}$ & $\ddot{*}$ & $\ddot{.}$ & $\because$. & \\
\hline$\ddot{n}$ & $\begin{array}{c}\text { A few bacilli. } \\
. .\end{array}$ & $\ddot{+}$ & $\begin{array}{l}980 \\
490\end{array}$ & $\begin{array}{l}2 \text { drops. } \\
1 \text { drop. }\end{array}$ & $\begin{array}{c}\text { Alkaline. } \\
. .\end{array}$ & $\begin{array}{l}0 \\
\cdots\end{array}$ & $\begin{array}{l}+ \\
\cdots\end{array}$ & " \\
\hline$\ddot{0}$ & $\ddot{0}$ & $\ddot{0}$ & $\begin{array}{r}524 \\
0\end{array}$ & 2 drops. & Neutral. & $\ddot{+}$ & $\begin{array}{l}\cdots \\
\cdots\end{array}$ & \\
\hline $\begin{array}{c}\text { Bacilli, but } \\
\text { no blood- } \\
\text { corpuseles } \\
\text { found. }\end{array}$ & $\begin{array}{l}\text { Bacilli. } \\
\quad \because \\
\quad \cdot\end{array}$ & $\begin{array}{l}+ \\
\ddot{.}\end{array}$ & $\begin{array}{c}\text { Conntless. } \\
\text { "1 }\end{array}$ & $\begin{array}{c}\text { A trace. } \\
" 1 "\end{array}$ & $\begin{array}{c}\text { Alkaline. } \\
: . \\
.\end{array}$ & $\begin{array}{l}+ \\
\therefore \\
\therefore\end{array}$ & $\begin{array}{l}. . \\
\ddot{.}\end{array}$ & $"$ \\
\hline $\begin{array}{l}\text { Bacilli and } \\
\text { blood- } \\
\text { corpuscles. }\end{array}$ & $\begin{array}{l}\text { Bacilli and } \\
\text { blood- } \\
\text { corpuscles. }\end{array}$ & + & $"$ & 1 drop. & Alksline. & + & .. & Extravasations found. \\
\hline $\begin{array}{l}\text { Bacilli (no } \\
\text { blood- }\end{array}$ & $\begin{array}{l}\text { Bacilli. } \\
\text {.. }\end{array}$ & + & "" & A trace. & ".. & $\begin{array}{l}+ \\
\therefore\end{array}$ & $\ddot{n}$ & No extravasations found \\
\hline $\begin{array}{c}\text { corpuscles } \\
\text { detected). } \\
0 \\
0\end{array}$ & $\stackrel{0}{0}$ & $\stackrel{+}{0}$ & $\begin{array}{r}284 \\
0\end{array}$ & $\begin{array}{l}1 \text { c.c. } \\
18 \text { drops. }\end{array}$ & $\begin{array}{c}\text { Alkaline. } \\
\text { Slightly } \\
\text { aeid. }\end{array}$ & $\begin{array}{l}0 \\
0\end{array}$ & $\begin{array}{l}0 \\
0\end{array}$ & Not examined. \\
\hline $\begin{array}{l}0 \\
0\end{array}$ & $\begin{array}{l}\mathbf{0} \\
\mathbf{0}\end{array}$ & $\begin{array}{l}0 \\
+\end{array}$ & $\begin{array}{r}0 \\
102\end{array}$ & $\begin{array}{l}-1 \text { c.c. } \\
0 \text { c.c. }\end{array}$ & $\begin{array}{l}\text { Alkaline. } \\
\text { Slightly } \\
\text { acid. }\end{array}$ & $\begin{array}{l}\mathbf{0} \\
\mathbf{0}\end{array}$ & $\begin{array}{l}0 \\
0\end{array}$ & No extravasations found \\
\hline $\begin{array}{l}\text { Bacilii (no } \\
\text { blood- } \\
\text { corpuscles }\end{array}$ & Bäilli. & $\ddot{+}$ & $\begin{array}{c}137 \\
\text { Conntless. } \\
\text { (2nd plate, } \\
5170 .)\end{array}$ & $\begin{array}{l}\text {-4 c.c. } \\
2 \text { drops. }\end{array}$ & Alkäline. & $\ddot{0}$ & $\ddot{+}$ & \\
\hline $\begin{array}{l}\text { found). } \\
\text { found }\end{array}$ & .. & .. & $\begin{array}{c}\text { Countless. } \\
\text { (2nd plate, } \\
\text { 10990.) }\end{array}$ & 5 drops. & .. & .. & .. & $"$ \\
\hline .. & .. & .. & $\begin{array}{l}\text { Countless. } \\
\text { (2nd plate, } \\
\text { 3195.) }\end{array}$ & 2 drops. & Iי & .. & $\cdot \cdot$ & \\
\hline 0 & $\mathbf{0}$ & $\begin{array}{l}0 \\
. .\end{array}$ & $\begin{array}{c}0 \\
0\end{array}$ & 1 c.c. & Alkaline. & 0 & $\begin{array}{l}0 \\
. .\end{array}$ & \\
\hline$\ddot{0}$ & $\ddot{0}$ & $\ddot{0}$ & $\begin{array}{l}0 \\
0\end{array}$ & $\begin{array}{l}4 \text { c.c. } \\
\text { iz c.c. }\end{array}$ & Alkaline. & 0 & o & \\
\hline$\ddot{0}$ & $\ddot{0}$ & $\ddot{0}$ & 0 & 8 c.c. & Alkäline. & $\ddot{0}$ & $\ddot{0}$ & \\
\hline $\begin{array}{l}0 \\
0 \\
. .\end{array}$ & $\begin{array}{l}0 \\
0 \\
. .\end{array}$ & $\begin{array}{l}\mathbf{0} \\
0 \\
. .\end{array}$ & $\begin{array}{l}0 \\
0 \\
0\end{array}$ & $\begin{array}{l}2 f \text { c.c. } \\
4 \text { c.c. } \\
2 \text { c.c. }\end{array}$ & "." & $\begin{array}{l}0 \\
0 \\
0\end{array}$ & $\begin{array}{l}\mathbf{0} \\
0 \\
0\end{array}$ & \\
\hline $\begin{array}{l}\ddot{0} \\
0 \\
. .\end{array}$ & $\begin{array}{l}\ddot{0} \\
0 \\
. .\end{array}$ & $\ddot{0}$ & $\begin{array}{r}0 \\
0 \\
0\end{array}$ & $\begin{array}{c}5 \frac{1}{2} \text { c.c. } \\
3 \text { c.c. } \\
\text { a }\end{array}$ & "1" & $\begin{array}{l}0 \\
0\end{array}$ & $\begin{array}{l}04 \\
04\end{array}$ & \\
\hline
\end{tabular}

4 The urine was distinctly tinged with the green tint of the culture, although none of the bacilli were found in it. 
entered on the foregoing list as "found dead." They are admitted in the belief, from evidence at the autopsy, that the animals had, when then examined, been dead only a short time.

In reviewing the above results, it must be remembered that the number of bacilli present in the sample of urine examined was not necessarily a quantitative guide to the number of germs possibly passing through the secreting membrane, because the rate of secretion was unknown, and especially because in certain cases the micro-organism throve in the urine, and, at the body temperature, in the course of a few hours might have multiplied considerably in that fluid. It will have been noted that the search with the spectroscope for hæmoglobin was carried out in a number of cases, without there proving reason to suspect the presence of blood; but it will be remembered that it was impossible to foretell, before the plate-cultures had had time to grow, whether there would or would not be ground for that suspicion. In the series of experiments, the Koch method of examination by platecultures showed itself a much more delicate means of search for bacteria than the careful examination of films, drops, or sections (fresh or unstained) merely by the microscope. In the sixty-eight observations, the presence of the specific micro-organism introduced was detected twenty-one times: on eight of these twenty-one occasions the presence of blood in the urine was ascertained, and in a ninth case gross lesions (tubercle) were found in the kidney. The species appearing in the urine, without the urine being in every case sanguineous, were $B$. mallei, $B$. anthracis, B. murisepticus, B. pyocyaneus, and the (?) pneumo-bacillus; and they were found thus, twelve times in all, but twice in these twelve times the urine containing them contained also much coagulable proteid.

Although, in the tabulated results, I have assumed that the presence of hæmoglobin in the urine was equivalent to the presence of red bloodcorpuscles in that fluid, one need hardly say that the assumption is liberal to those who hold that bacteria escape through a secreting membrane only when there is hæmorrhage across it. The experiments of Adami ( ${ }^{45}$ ) have shown that an innocuous solution of hæmoglobin introduced into the circulation escapes rapidly in the urine from perfeetly healthy kidneys. In Adami's experiments the presence of hæmoglobin in the urine did not evidence a damaged condition of the renal membrane, far less a ruptured one. Although I have interpreted the presence of hæmoglobin in the urine as equivalent to that of actual blood, it is not therefore necessarily so. If any laking of the blood occur in certain bacterial diseases, it seems almost certain that hæmoglobinuria will follow as its result. I merely mention this to indicate that the assumption made above is really more favourable to the view of the escape of germs in the urine being due to breach of continuity of the renal membrane than, in fact, satisfies the evidence.

That the passage of bacteria into the urine is effected by the agency 
of leucocytes is a possibility, but has little actual evidence in its support. In the above experiments it suggests itself with most force in the case of $B$. murisepticus. There, although the septicæmia runs a fatal course, the leucocytes contain the bacilli in numbers. The microscope did not reveal leucocytes, either in the urine or in the renal tubules; further, the bacteria in leucocytes are usually supposed to be dead or dying. A careful search in the experiments with the capsulated bacillus, probably Friedländer's, did not reveal the germs inside the leucocytes.

The Bile.-Observations on the passage of micro-organisms into the bile were made in the same way as those on the urine. The bile was always obtained from the gall-bladder by piercing an eschar made in the wall (post-mortem) with a fine sterilised capillary pipette, into which the fluid ascended by capillarity. Experiments on the mouse offer the advantage that, if desired, the whole quantity of the bile may be easily subjected to test-cultivation. Also the presence or absence of blood-pigment in mouse bile, MacMunn $\left({ }^{46}\right)$, can be ascertained with extreme readiness, as the absorption spectrum of that bile offers no bands at all between the solar lines $\mathrm{D}, \mathrm{E}$. In comparing the quantity of bile examined with the quantity of urine where both are measured by drops, it must be remembered that bile gives a much smaller drop.than urine, since its surface tension is much less.

As regards a source of error due to the possible destruction of the micro-organisms by the bile, I have controlled that to the same extent as with urine, and found that none of the species I used are obviously injured by eight hours' immersion in the bile of the guinea-pig. Copeman and Winston ${ }^{47}$ ) have shown that $B$. anthracis, $B$. finkleri, $B$. cuniculicida, and $B$. prodigiosus, will grow in ox bile and in human bile, observations agreeing with some by myself (vide the above paper) on Spirillum choleroe asiatico, Eberth's bacillus (B. mallei), and Ribbert's bacillus of enteritis of rabbits. Corrado $\left({ }^{28}\right)$ relates that bile in eighteen hours destroys the virulence of $B$. anthracis, and that it exerts a marked retarding influence on its growth. On the other hand, he finds that bile has no effect on Staphylococcus pyogenes aureus, nor on the pneumobacillus, and is favourable to the growth of $B$. mallei. Blachstein $\left({ }^{25}\right)$ has recently called attention to the prolonged time for which $B$. typhi abdominalis will live in rabbit's bile. See Tables on pp. 272 and 273.

It will be seen from the tabular statement that, in the forty-nine experiments, the specific bacteria were detected in eighteen; in six of those eighteen blood was also found to be present, as likewise in two cases in which bacteria were absent from the bile. ${ }^{1}$ The bacterial

I In each of these two cases the autopsy was not carried out immediately after death. The appearance of hæmoglobin in the bile, a short time after death, is a well-known phenomenon; cf. among others, Wertheiner, Archives de Physiol. norn. et path., 1889, p. 747. 


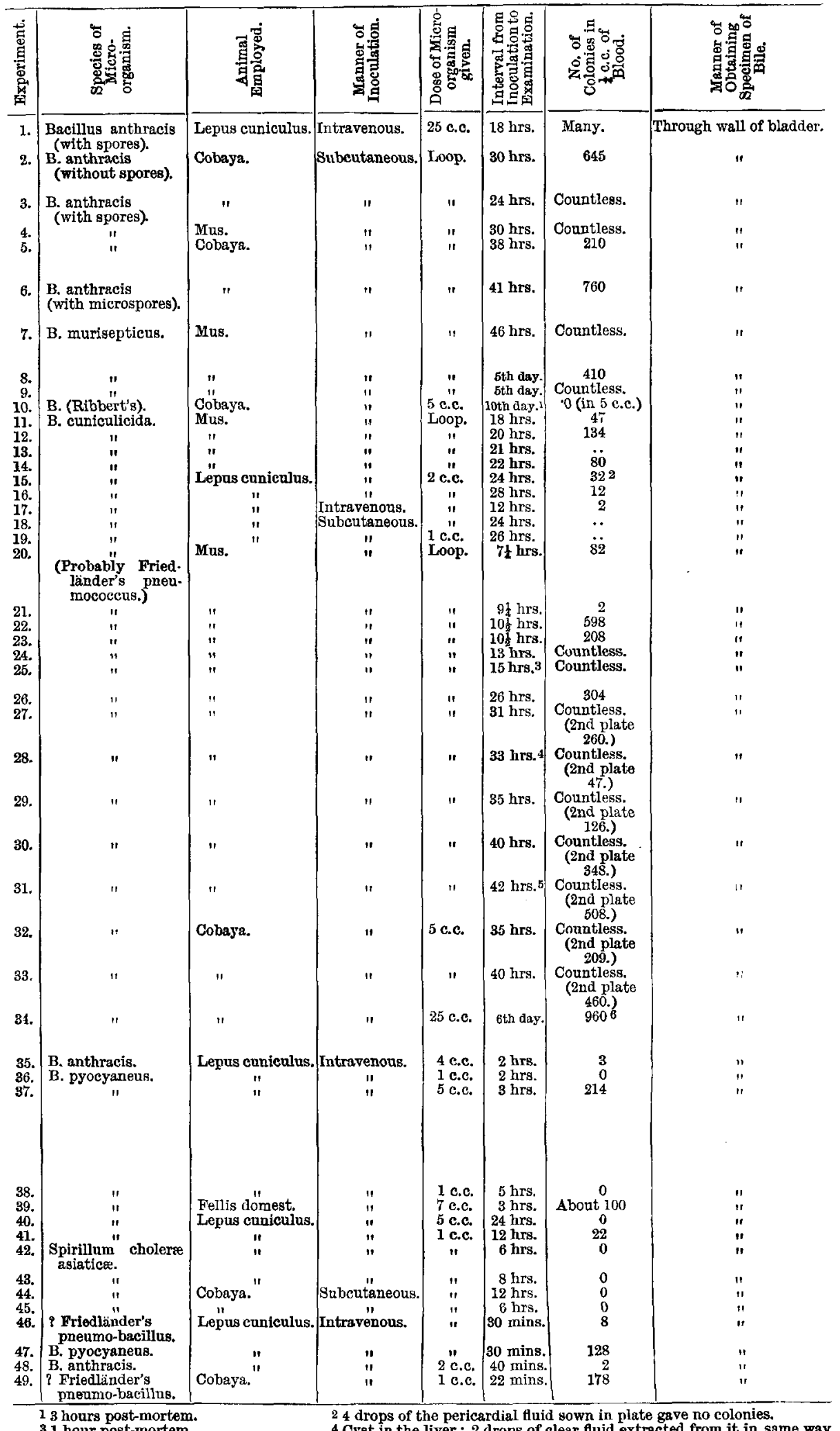




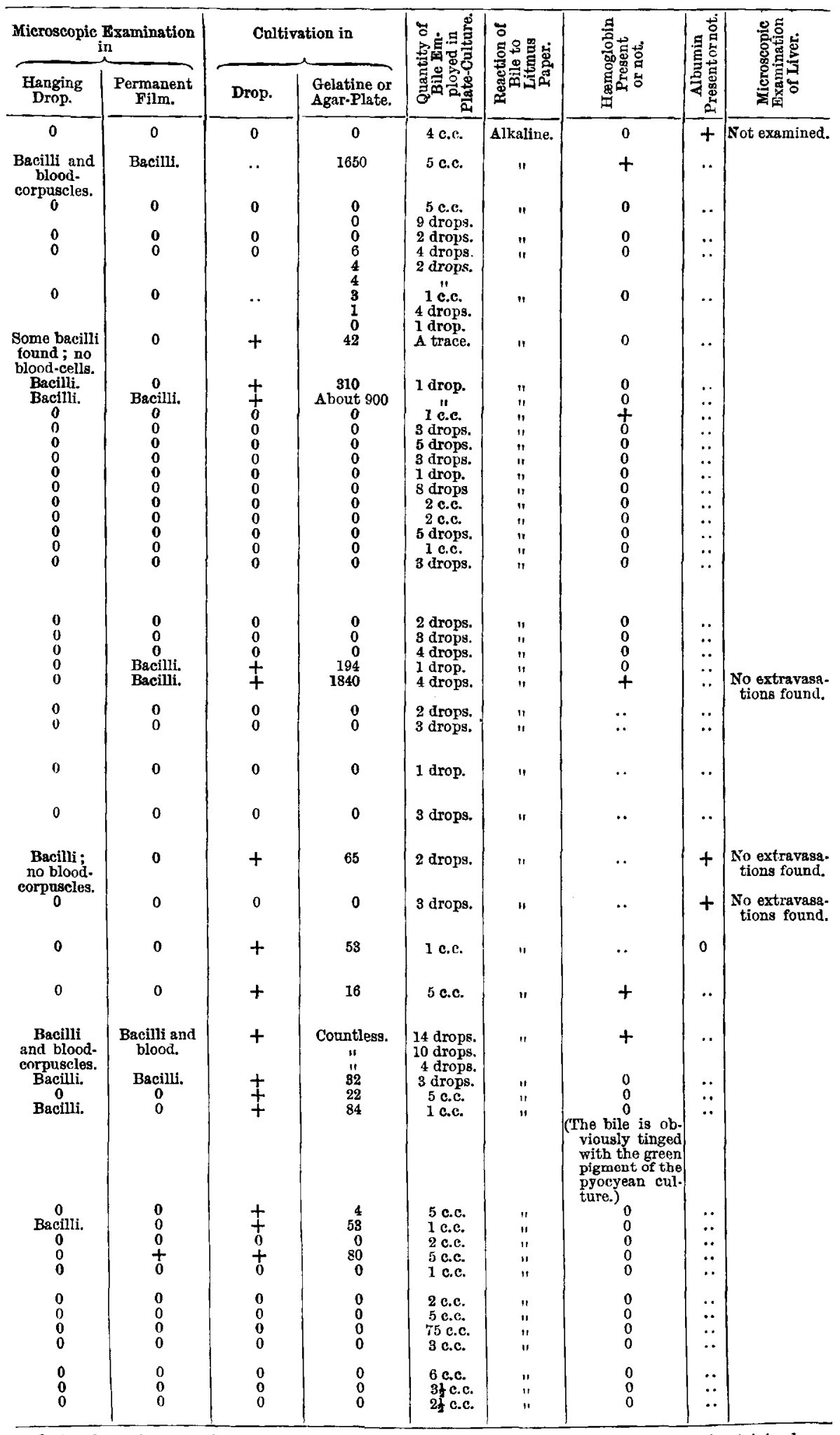

6650 colonies in a small drop of emulsion of the washed kidney: but $\cdot 5$ c.c. of pericardial fluid (containing leucocytes but no red corpuscles) gave not a single colony in 3 plates found; also no colonics from is drops of urine cytes but no red corpuscles)
(other list, experiment 60).

JI. Or PATH $\rightarrow$ rou 
species thus escaping into the bile were $B$. anthracis, $B$. pyocyaneus, $B$. murisepticus, and the (?) pneumo-bacillus; that is to say, four of the five species which were detected in the urine in the other series of observations. There seems, with these species, a somewhat greater tendency to pass into the bile than into the urine in the animals here experimented upon.

It will be noted that in the same individual case the bacteria may appear in the urine but be absent from the bile, or vice versa; an indication of the local character of the conditions which determine their transit through the secreting membrane.

In no case did the bacteria excreted with the urine or the bile appear to have suffered change or injury in the process. Their virulence had not obviously diminished when they were used for subsequent inoculation; their rate of growth in artificial culture showed no obvious alteration. B. pyocyaneus produced its colouring matter as under other circumstances.

The Aqueous Humour.-A few examinations of the aqueous humour were also made by the same method resorted to for bile and urine. In the freshly-killed animal an eschar was made involving the whole thickness of the cornea, and through this the sterilised needle of a Koch's syringe was introduced obliquely without its touching the iris. See Table on p. 275.

It will be noted that in none of the few experiments made were either blood or the bacilli detected in the aqueous humour, although the latter were in more than half the cases present, in numbers, in the circulation.

In three of the mice incoulated with $B$. murisepticus a trace of the white muco-purulent conjunctival secretion, which is so marked a symptom in Koch's mouse septicæmia, was transferred with a platinum loop to gelatine, and examined by plate-cultures. Each time it was found to contain great numbers of $B$. murisepticus; there had been little chance of direct inoculation of the conjunctiva locally, as the inoculation had been made at the side of the tail, and each mouse placed apart in a separate clean cage. Examined microscopically the secretion contained granular pus or mucous cells, but no red blood-corpuscles.

In two mice inoculated with $B$. cuniculicida the conjunctival secretion was examined for the bacillus without it being discovered, 18 hours and 22 hours after inoculation. The pneumo-bacillus was in one instance present in the contents of a parasitic cyst in the liver, when absent from the bile contained in the gall-bladder.

Points which appear to me of interest in the above experiments are the following:-

At a time when every drop of the circulating blood is teeming with micro-organisms there may not be the slightest transit of them into the urinary and biliary fluids then secreted; and they may be completely absent from the aqueous humour of the eyeball. 


\begin{tabular}{|c|c|c|c|c|c|c|c|c|c|}
\hline 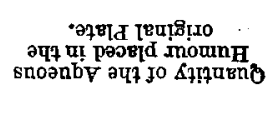 & 离 & 兽 & 密 & & 兽 & 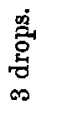 & 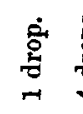 & 总 & $\therefore$ \\
\hline 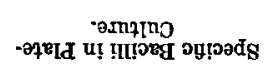 & 0 & 0 & o & 0 & 0 & 0 & 0 & ○ & 0 \\
\hline 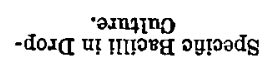 & 0 & 0 & 0 & 0 & $\circ$ & 0 & 0 & $\circ$ & - \\
\hline 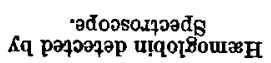 & $\odot$ & $\circ$ & ○ & $\circ$ & $\circ$ & 0 & 0 & 0 & 0 \\
\hline 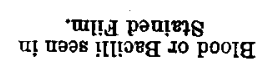 & $\circ$ & 0 & 0 & 0 & $\circ$ & o & 0 & o & ○ \\
\hline 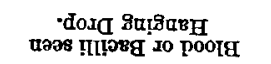 & o & $\circ$ & $\circ$ & 0 & $\circ$ & 0 & 0 & 0 & 0 \\
\hline 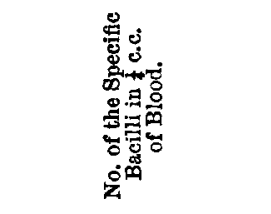 & 0 & & 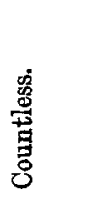 & $\infty$ & 总 & 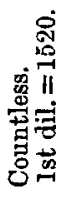 & 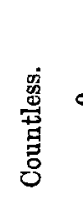 & 0 & $\mathbb{N}_{N}$ \\
\hline 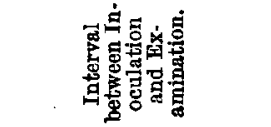 & 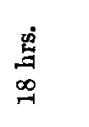 & 兽 & 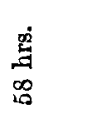 & 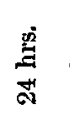 & 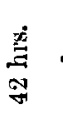 & 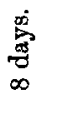 & $\underset{\substack{g \\
\rightarrow}}{\stackrel{\infty}{\rightarrow}}$ & 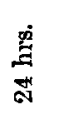 & $\frac{d}{\infty}$ \\
\hline 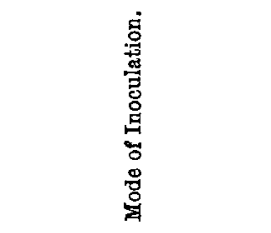 & 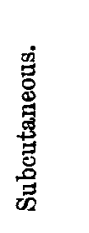 & 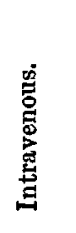 & $\therefore$ & $=$ & & 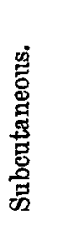 & $=$ & 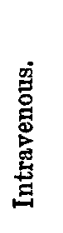 & 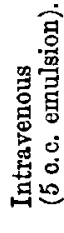 \\
\hline 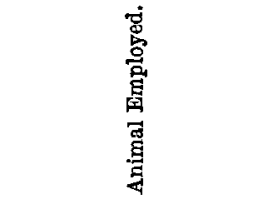 & 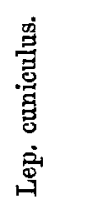 & $\therefore$ & $:$ & $=$ & & 帚 & 急. & 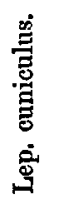 & 2 \\
\hline 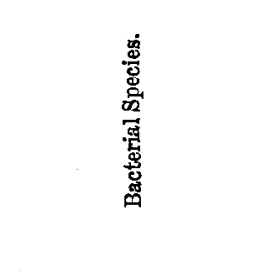 & 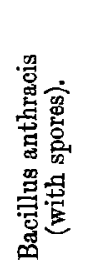 & $=$ & 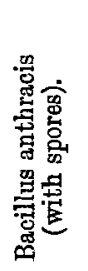 & 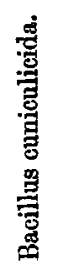 & $=$ & 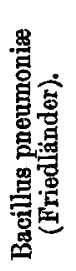 & $=$ & 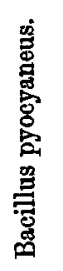 & $=$ \\
\hline 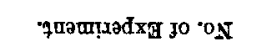 & - & $a$ & $\infty$ & 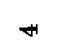 & so & $N$ & $\infty$ & $\infty$ & $\infty$ \\
\hline
\end{tabular}


When several millions of micro-organisms are injected into the blood-stream they rapidly, as Watson Cheyne $\left({ }^{39}\right)$, Fodor $\left({ }^{48}\right)$, Wyssokowitsch $\left({ }^{19}\right)$, Franck and Lubarsch $\left({ }^{49}\right)$, and others have shown, disappear from the circulating blood, and, as Wyssokowitsch has shown, the disappearance of them is not by way of the urinary and biliary secreta. This is true for motile and non-motile, for pathogenic and for innocuous species.

When certain pathogenic species are employed, a number, often very considerable, of the injected bacteria, tend after a time to appear in the secretions of the kidney and the liver, and their escape in the secreta is sometimes accompanied by an escape of actual blood.

Not unfrequently in the case of these species, although there is no blood either in the urine or in the bile, the bacteria nevertheless escape vid the kidney and the liver; but in these instances there may be present in the secreta of those organs a considerable amount of proteid, although there is no blood.

I conclude that these experiments do not support the suggestion of Cohnheim that the body, in the event of bacterial invasion, protects itself by excreting the living germs through the kidneys and through the liver; nor do the experiments, on the other hand, confirm the view that bacteria escape in the secreta only when the blood itself containing them escapes; sometimes there appears a transit of the bacteria across the renal and hepatic membranes, without detectable transit of the blood. But the evidence is against believing that when this transit of bacteria across the secreting membrane occurs, the membrane is still normal in condition, although at the same time it need not be ruptured or pervious to red blood-corpuscles. The membrane is rather to be regarded as then exhibiting, in a minor degree, the pathological change, which, when increased, will render it pervious to the same extent that the capillary wall becomes pervious in an area of inflammation. The fact that the escape of the bacteria tends to occur, not immediately upon the introduction of them wholesale into the circulation but in the late stages of the communicated disease, suggests that the healthy secreting membranes are not pervious to bacteria, and that only after soluble poisons produced by the infection have had time to act upon them do the membranes become pervious to the germs. The fact that species which are innocuous did not in the experiments appear in the secreta at any time is in conformity with this conclusion.

Among the species observed to escape through the membranes, even in absence of escape of blood, are some that are non-motile; this suggests that in their transit across the secreting membrane the bacteria themselves are passively conveyed, that the transit is less an active migration than a passive transference.

I take this opportunity of thanking Professor Robert Koch, in whose laboratory the above experiments were commenced, for the kindly criticism and advice afforded to me at the time. 


\section{BIBLIOGRAPHY.}

1. Hoffman and Langermaud, Virchow's Archiv, 1869, Bd. xlviii., p. 303.

2. Rütrmeyer. . . . . Arch. $f$. exp. Path., 1881, Bd. cxli., p. 393.

3. Bridges Adams, . . . Hämoglobin ausscheidung in d. Niere, 1880.

4. Wiener, . . . . . Arch. f. exp. Path., Bd. xi., p. 275.

5. MAAs, . . . . . . Deutsche Zeits. f. Chir., vol. xii., p. 118.

6. Grawitz, . . . . . Virchow's Archiv, Bd. lxx., p. 546.

7. Kannenberg, . . . . Zeits. f. Klin. Med., 1880, p. 506.

8. Phillippowicz, . . - Wien. med. Blätter, 1885, Nos. 22 and 23.

9. Ferraresi and Guarnieri, Atti d. r. Acc. Med. di Roma, 1887, vol. iii.

10. Finkumr and Prior, . . Centralbl. $f$. allg. Gesundheitspflege, vol. i., Nos. 5 and 6.

11. Tizzont and Cattani, - La Riforma Med., 1888, No. 93.

12. ЕммеRісн, . . . . . Arch. f. Hygiene, vol. ii., p. 357.

13. MAY, . . . . . . Arch. f. Hygiene, vol. i.

14. Bang, . . . . . . Deutsche Zeits. f. Thiermedicin, 1885, vol. i., p. 45.

15. Koubasoff, . . . . Centralbl. f. d. ges. Medicin, 1885, No. 44.

16. Cavagnis, . . . . Atti d. r. Istit. Veneto di scienze, 1888, Part vi.

17. Escherich, . . . . . Fortsch. d. Medicin, 1885, vol. iii., No. 8.

18. LongaRD, . . . . Arb. a. d. path. Instit. zu Munchen, 1886, pp. 181-197.

19. WYssokowitsch, . . . Zeits. f. Hygiene, 1886, vol. i., p. 3.

20. KoujaJefF, . . . . . Abstr. in Centralbl. f. Bakt. u. Parasitenk., 1889 , vol. vi., p. 672 .

21. Neumane, . . . . Berlin. klin. Woch., 1890, p. 229.

22. KarLinski, . . . . . Prager med. Woch., 1890, p. 231.

23. Trambusti and Maffucci. Rivista internaz. di Med., 1886, No. 9.

24. Charrin, . . . . . La Maladie pyocyanique, 1889, Paris.

25. Blachstein, . . . . Bull of the Johns Hopkins Hospital, Baltimore, vol. ii., 1891, No. 14, p. 96.

26. Corrado,

Atti d. r. Acc. Med. di Roma, 1891, vol. i., p. 49.

27. Charrin and Ruffer, . Compt. rend. Soc. de biol., 13th Oct. 1888.

28. RufFer, . . . . . Nat. of the Dis. produced by B. pyocyaneus, London, 1889.

29. BabÉs, . . . . . . Comptes Rendus, Paris, 1888.

30. Connil, . . . . . . La Semaine méd., 1890.

31. Rotн, . . . . . . Zeits. f. Hygiene, 1888, vol. iv., p. 1.

33. Sonimmelbusor, . . . Deutsch. Natur. f. und Aert. Versamml, 1888.

33. AhlFeld, . . . . . Centralbl. f. Gynäkologie, 1877, No. 15.

34. Max WorfF, . . . . Virchow's Archiv, 1888, Bd. exii., p. 136.

35. Lingard. - . . . . Proc. Roy. Soc., London, 1889.

36. Brrot - Hirsohfeld and Virchow's Archiv, Bd. exxiv. LUBARSGH.

37. Pasteur, . . . . . Comptes Rendus, 1863, vol. lvi., p. 738.

38. LISTER, . . . . . . Trans. Roy. Soc. Edin., 1875.

39. Watson Cheyne, . . . Trans. Path. Soc., London, 1875.

40. Mrissner, . . . . . Medic-Naturwissen. Béi., Göttingen, 1879.

41. Cohnheim, . . . . . Vorlesungen iib. allgem. Pathol., 1882, vol. ii., p. 188.

42. UfFelmane, . . . . Berlin. klin. Woch., 1887, p. 726.

43. Brauell, . . . . . Virchow's Archiv, 1857, Bd. xi., p. 132. 
44. Delafford, . . . . Bull. d. 1. Soc. Cen. Vétérin (Recueil d. méd. vét., p. 726).

45. Adami, . . . . . . Journal of Physiology, 1885, vol. vi., p. 382.

46. MaoMunN, . . . . The Spectroscope in Medicine, London, 1880, p. 158.

47. Copeman and Winston, Journal of Physiology, 1890, vol. x., p. 213.

48. von FoDor, . . . . Sitzber. d. Math. Naturwissen. Classe der Ungarisch. Akad. der Wissensch. 18. v., 1885.

49. Frank and Lubarsci,, . Zeits. f. Hygiene, 1891.

50. K. B. LemmanN, . . . Münchener med. Woch., 1887, No. 26.

51. Penice and Scagliosi, . La Riforma Med., 1892, Nos. 97, 98.

52. Enriquez, . . . . . La Semaine méd., 1891, p. 468.

53. S. G. Shatrock, . . Trans. Path. Soc., London, vol. xliii., p. 200.

54. Strads and Chamberland, Comptes Rendus, Paris, 1885.

55. Kroner, . . . . . Breslauer aertzlich. Zeitschrift, 1886.

56. Landouty (AND H. Revue de médecine, 1891 (Expt. 1883). MaRTIN).

57. Birch-Hirschfeld and Beitr. zu pathol. Anat., 1890, p. 429. SCHMORL.

58. Schweizer, . . . . . Virchow's Archiv, 1887, Bd. cx., p. 2.

59. Sanchez-Tolmdo and Annales de l'Institut Pasteur, tome ii., p. 427. Straus.

60. Dobroklouskr, . . . Cited by Arloing, Leçons sur la Tuberculose, Paris, p. 121.

61. Nocard, cited by Roux, L'Immunité. Trans. of the Ninth International Congress of Hygiene and Demography, Section II.

62. Bang, . . . . . Comptes Rendus de la Congrès de la Tuberculose. Deutsche Zeits. $f$. Thiermed. und vergleichende Pathologie, 1890, vol. xvii., p. 1. Trans. of the Ninth International Congress of Hygiene and Demography, Section II. 